\title{
Innovation and Change in Approaches to Balinese Gamelan Composition
}

\author{
I Komang Sudirga \\ Music Department, Faculty of Performing Arts \\ Institut Seni Indonesia, Denpasar \\ Jalan Nusa Indah, Sumerta, Denpasar, Bali, 80235 \\ e-mail: ksudirga3@gmail.com \\ *Corresponding author: ksudirga3@gmail.com
}

Published: 10 September 2020

Cite this article (APA): Sudirga, I. K. (2020). Innovation and change in approaches to Balinese Gamelan composition, Malaysian Journal of Music, 9, 42-54. https://doi.org/10.37134/mjm.vol9.4.2020

\begin{abstract}
This article addresses newly developed approaches to gamelan composition among Balinese composers by focusing on changes and innovations within tradition. Balinese composers today represent a cross-section of arts communities who collectively have produced some of the most innovative gamelan compositions in nearly half a century. Subjected to increasingly cosmopolitan reviews from both conservative and progressive audiences, these composers encapsulate the shifting ideals of a generation who value new aesthetic paradigms that increasingly diverge from the history, tradition and legacy of their traditional Balinese predecessors. In the fiercely competitive world of gamelan group rivalry, struggles and triumphs between contemporary composers have always seen creative boundaries pushed to their limits. I examine some of these triumphs and limitations by examining the creative output of six representative Balinese composers who contend with innovation and its reception in local contexts. I argue that innovations in gamelan serve as benchmarks that demarcate creative spaces and approaches while simultaneously testing the real-world confines of changing traditions.
\end{abstract}

Keywords: Balinese gamelan, contemporary composition, cultural matrices, innovation

\section{Introduction}

Audiences who support new compositions may feel confident that the presentation of contemporary music can, at the view least, provide some new ideas and innovations to existing music traditions. However, many new ideas may be controversial and bring to the surface mixed reactions and responses particularly from conservative audiences on the Indonesian island of Bali. Although sometimes less conceptually understood, contemporary gamelan composers may be abrasive and challenge the status quo in their attempts to be entertaining. Audience members who reject composer's radical ideas in a creative work apply critiques that alienate gamelan artists because they feel radically new compositions to be strange, not accessible and lacking established musical references.

In order to carry out an investigation of these issues, this article examines recent innovative works from six Balinese composers who are challenging tradition and spawning new art forms. I Wayan Sudiarsa is regarded as a 'community composer' who attributes his innovations and inspirations to two general categories: environmental themes and making social impact. As a grassroots composer he is less concerned with notions of recognition and stardom and focuses on composing to make a positive impact on his local community. I Nyoman Windha is a veteran in kebyar innovations. He innovates by using the geo-cultural location of his composition as an impetus for creating his works. For Windha innovating involves evaluating where you are, the musicianship of the group, and how best to compose for them. I Wayan Darya from the village of Singapadu got his idea to create an entirely new gamelan only after collaborating with the dancer Guruh Soekarnoputra. This reaffirms that music composition 
in Bali does not operate in a vacuum but has a symbiotic relationship with performing arts. Bona Alit and I Made Subandi each have explored diatonic music and pan-Asian instruments such as Indian tabla and Chinese erhu for collaborations for composition. And finally Dewa Ketut Alit has become a visionary by continually testing the boundaries of tuning, orchestration and instrumental possibilities for gamelan. Each composer innovates new ideas while negotiating what changes affect their personal directions and traditions they represent.

Using the notion of cultural matrices (Brinner, 1995) as the intersection of reference points that dramatically shape innovation in gamelan works, this article looks at what informs composer's choices for gamelan compositional reconfigurations. It also examines how innovations are justified and qualified to demarcate space within a composer's pallet of expression while simultaneously assessing the boundaries of changing traditions. Balinese composers have been innovating new ideas for generations. There is a long lineage of Balinese composers such as I Gede Manik and I Wayan Beratha who are considered pioneers of the revolutionary $20^{\text {th }}$ century style of gamelan called kebyar. We now look back at how gamelan traditions have been passed down and how composers adhere to their teacher's style while innovating their own idioms and approaches.

\section{Histories of Innovation in Balinese Performing Arts}

The idea of innovation among composers and choreographers for contemporary Balinese gamelan music and dance is not new. Each inheriting generation in Bali has made efforts to renew their ideology to express their concepts and worldviews through gamelan music (Dibia, 1999). Many examples of innovation in the history of Balinese performing arts are worthy of note in this discussion of innovation. In 1915, the North Balinese dancer, Pan Wandres from the village of Jagaraga in Buleleng district used the classical court dance called legong kuntir as a basis for innovating movements in the fast and flashy style that would become kebyar and the classic dance called kebyar legong. This dance would inspire composer/choreographer I Gede Manik to compose the revolutionary dance and music called kebyar truna jaya that is today considered a benchmark of dance and music (Tenzer, 2000). In 1925, the dance maestro from the district of Tabanan, I Ketut Mario (1897-1968) used the agility of the gandrung to innovate it into the now classical choreography called kebyar duduk. Later in 1952, he would create a duet for male and female dancers called oleg tamulilingan. Each of these examples were innovative in their time but have since become staples of a codified tradition.

This process of innovation becoming codified tradition also occurred in instrumental gamelan music. I Wayan Lotring (1898-1982) from Banjar Tegal in Kuta village, Badung regency combined compositional ideas from the classical court ensemble called gamelan palegongan together with repertoire from the quartet of metallophones called gender wayang to create his very own innovative compositions such as Sekar Gendot, Sekar Setaman and Kulicak (Bandem 2013). Historically, gamelan composers employed a great deal of 'musical borrowing' as methodology for innovation. Inter-genre borrowing has been common since the mid- $20^{\text {th }}$ century in Bali. For example, gong kebyar composers have traditionally borrowed from ensembles such as the stately temple music of gamelan gong gede, the seven-tone gambang and ritual ensembles like the gong luang. The sweet, melodic repertoire of instrumental music from the melodious and sweet-sounding court orchestra called semar pagulingan borrowed repertoire from the chamber ensemble of long end-blown flutes called pagambuhan. By the 1960s, the folk-inspired bamboo ensemble joged bumbung and the 4-tone bronze gamelan angklung adopted the flashy, fast paced style of kebyar.

Cross-genre borrowing as a methodology for innovation was not limited to musical ensembles. The late theorist and music scholar, I Gusti Putu Made Geria from Buagan village in Denpasar, who was also a composer of the generation of Nyoman Kaler and Wayan Lotring, had the skill and ability to create the long, extended musical compositions of instrumental music for tabuh lelambatan pegongan klassik based on his wealth of musical knowledge about vocal music (tembang Bali) using poetic verse forms such as Ginada, Pangkur, Dangdang, and Sinom. Not unlike I Wayan Lotring's new percussion works cited above, I Gusti Putu Made Geria also mastered the palegongan and kakebyaran forms composing complicated interlocking parts because he had a strong base both in terms of seamlessly fusing gender wayang, pagambuhan, and palegongan percussion techniques. He was also a lecturer in music at the then ASTI Denpasar and had students such as I Nyoman Rembang, I Wayan Sinthi, and I Wayan Beratha. 
Composition lineage continued in the hands of Geria's student, I Wayan Beratha, a figure who earned the reputation from his peers and the wider community in his generation as the reformer of kebyar style gamelan. In addition to creating new instrumental music in the style of temple orchestras called kebyar lelambatan, he was influential in choreography for the nationalist farmer's dance called tari tani because during the presidency of Sukarno, "... Balinese artists were encouraged to write music that expressed themes of national interest in a social realist style" (Steele, 2013, p. 186).

Innovations from the lineage of Balinese composers continued when I Wayan Beratha then handed down his expertise to his pupils such as I Wayan Rai. S, I Nyoman Astita, I Ketut Gde Asnawa, I Wayan Sinti, I Nyoman Windha, I Nyoman Sudarna, Desak Suarthi Laksmi, and others who are considered great composers of this era. Among the most productive and prominent students of Beratha was I Nyoman Windha. Never resting on his laurels, the results of his work adhere to his teacher's style, but have led to his own innovative idioms in his language of music. His strength is strongly rooted in the structure of his melodies enriched by a virtually endless repository of melodic nuance and variation. In the 1990s, a new generation of young composers emerged such as I Gde Arya Sugiartha, I Made Arnawa, I Gde Yudana, I Nyoman Sutama, I Wayan Widia, I Wayan Darya, I Made Subandi, I Wayan Wiriadi (Kiung), Dewa Ketut Alit, Sang Nyoman Arsa Wijaya, I Ketut Suandita, I Wayan Sudirana, and I Wayan Sudiarsa (Pacet). The exciting developments of contemporary composers Wayan Gde Yudana, Dewa Ketut Alit, Wayan Sudirana, and Sang Nyoman Arsa Wijaya bring even more radical new challenges in the composition of Balinese gamelan.

The next section of this article explores some of the theoretical frames contemporary composers consider when creating compositions. Unlike their predecessors, today's composers in Bali depart from tradition to create forms and structures that previously have not been done before where "breaking existing molds" is part of the process of generating new ones (Brinner, 1995, p. 452).

\section{Innovation Conceptualised}

Innovation constitutes a strategic move that intentionally departs from tradition to update a particular culture to be more functional for its audience. Often glossed as an invention of tradition (Hobsbawm \& Ranger, 1983), innovations also involve developing solutions to artistic problems. If the invention takes the form of a working model or prototype, then the concept of innovation relates to creations that are generally new tools, products, methods or processes that inform new perspectives. Riandi (2016) defines innovation as a way of dealing with challenging issues and sees "technical solutions to a technical problem" (p. 1). From the perspective of psychology, a new composition is perceived as original if its ideas, structures or forms have never been seen or heard before. The creator himself is 'cognitively convinced' something new has been generated; despite the fact that he may be unaware that elsewhere a new composition bearing similar traits may already exist.

From a cultural perspective, a new composition is meaningful if it previously did not exist in the cultural practice of the composer whose "contemporary explorations look outward, breaking molds rather than filling them" (Brinner, 1995, p. 452). These expressions are not inferior to tradition nor are they considered less than other contemporary compositions that combine cross-culture elements to form music (McGraw, 2009). In this case, innovations are cultural encounters reconfigured, modified and changed to suit existing categories of cultural production such as musical form, tuning system, dramatic character, movement vocabulary or regional costume variations. These are just some of the many distinctive performing arts subsets that form cultural matrices, "[ ... ] a set of categories created by the intersection of two or more sets of distinctions" (Brinner, 1995, p. 434).

Indonesian historian and archaeologist, Edi Sedyawati (1981), describes intersecting approaches between classical and contemporary modern art in the $20^{\text {th }}$ century. She says, "In the classical approach, art is a statement of intellectual idealism, based on a set of permanent symbolic systems, which can vary according to the ability of each artist's choice of motives, expressions and presentations, and ultimately how its appreciated" (as cited in Lindsay, 1991, p. 50). The contemporary approach emphasises the assessment of uniqueness in an art work. New works are considered truly "art" if born from an artist's personal insight unbound by any limitation. The main strategy of modernists of the 20th century were built upon freeing themselves from dependency on the basic concepts of tonal harmony, rhythm, and melody (Harjana, 2003). Therefore, in modernism, one of the artist's aims is emancipation and liberation from bondage, attachment, and restriction. 
Over the past 20 years, I have observed both intellectual idealism and sonic emancipation through modernism in the gamelan compositions of my conservatory students. Let me briefly provide an anecdote as an example. In 2005, I served as composition thesis portfolio advisor for Sang Nyoman Arsawijaya. The title of his composition was Geräusch. Named after the German word for "unpleasant noise", the composition did not use conventional musical instruments. Instead, the composer chose to write for pieces of crude metal pipes, grinders, and cracked bronze gongs. During the final recital at the then Indonesian Academy of Higher Arts in Denpasar (Sekolah Tinggi Seni Indonesia, Denpasar) spectators were somewhat shocked and almost terrorised by the deafening sound. Many audience members unfamiliar with this kind of 'sonic emancipation' from tradition covered their ears. Oddly enough I remember that some of Arsawijaya's examiners requested ear protection devices but these were not permitted. After the performance, several examiners questioned whether or not Geräusch actually constituted a musical composition suitable for examination? Some audience members were surprised, angry and even considered my student's composition blasphemous. As his supervisor, I felt worried but remembered John Blacking's 'music as organised sound' so of course for me, it was music as a representation of the expression of an artist through the media of sound.

At that moment I realised our gamelan community and most of its academic artists were not really prepared to accept a radical and somewhat extreme new music. Looking back on this event makes evident that intellectual idealism and sonic emancipation are part of a process where meanings about Balinese gamelan compositions must be contested, destructed and reconstructed from scratch (Tenzer, 2011).

This type of sonic emancipation in gamelan composition also occurred after the performance of a new percussive creation called Candra Klang at the Gong Kebyar Festival at the 2007 Bali Arts Festival. Similar to my student's composition using metal pipes, grinders, and cracked bronze gongs, Candra Klang challenged the aesthetic boundaries and audience expectations, including well-respected senior gamelan composers. At that time, the late maestro I Wayan Beratha made the comment, "apa ya gaena totonan jeg sing kena baan ningeh aji kuping ... cara dedaarane lalah bin misi pakeh sing nyidaang ben ngerasaang" (what in the world are they doing, this cannot be enjoyed by my ears ... just like food that is both too spicy and salty cannot be tasted as delicious) (Sugiartha, 2012, p. 6).

Beratha's indigestible food analogy speaks to aesthetic gaps between generations. When listening to these expressions, Beratha and the general public often accuse contemporary gamelan composers of being selfish, egotistical and only seeking self-satisfaction. From this uninitiated perspective, when contemporary composition changes aesthetics, it seems to be exclusive, only understood by "insiders", namely the experts in the field, the artists and their supporters (Harjana, 2003).

Developing new aesthetics needs to be given a space for continually cultivating an appreciation for new ideas in order to make a connection between artist and audience. In this regard, Balinese composer's innovative efforts in local and regional arts arenas must be reinforced and supported in order to accommodate their creative ideas. Balinese artists who have grand ideas should be able to implement them so that increasingly composers can renew audience's interest in developing traditions at the regional, national and international levels. The basic properties of new music in both past and present contexts has not changed dramatically. It is only that innovation is actually needed as a means to question the past, push aside irrelevant and obsolete art forms, and make aesthetic space for itself.

\section{Forms of Innovation}

In Balinese society today there has been a noticeable shift in interpreting the aesthetic value of karawitan art forms. In the past, a well-composed karawitan composition earned notoriety if it was original, contained philosophical references, or used a high level of virtuosic skill judged primarily on musical phenomenon. Today, the aesthetic value is not just musical sounds pleasing to the ear, but draw from a cross-cultural musical language that contains a "clearly articulated ideology present in new musical arrangements" (Harjana, 2003; Sugiartha, 2012, p. 2). In this section, I review the importance composers place on technical ability, post-modern ideologies, the reassignment of instrumental functions within the gamelan orchestra, and the deconstruction of traditional structural concepts.

Increasingly, contemporary Balinese composers have a strong practical ability as a drummer, melodic leader or orchestral director where technical capability becomes the foundation for crossing- 
cultures. For example, I Wayan Sudirana's Korean percussion fusion piece Jinggong from Gamelan Yuganada and I Made Sidia's Dewi Sri - The Quest for Balance theatrical multimedia collaborations with Peter Wilson are examples of contemporary composer's practical skills invested in cross-cultural resources. With these musical skills, Balinese composers are increasingly encountering concepts of modern and postmodern artforms that serve as rich resources for them to break traditional musical moulds.

Although there are exceptions, most composers aspire to have their creative works be received and accepted by some real or virtual audience. I Gede Arya Sugiartha (2012) has elaborated at length on three ideological matters artists consider including dedication, self-actualisation, and commercialisation. These three ideologies draw on postmodern aesthetics' close affiliation to "form follows meaning", "form follows function", and "form follows fun". When "form follows meaning" in the world of traditional gamelan composition, historical and religious ideologies reflect royalty, the pantheon of Hindu deities, and society. When "form follows function" the composition fulfills an aesthetic function that is more personal, social, or commercial. But when the ideology leans toward "form follows fun" a self-indulgent aesthetic distorts the logic of the previous two ideologies. There is also the issue of theories about gamelan constructed external to tradition that prove to be too "rigid and incompatible" with the practical and fluid approaches Balinese composers use (Wakeling, 2010, p. 2).

One of the most significant innovations in Balinese gamelan concerns the reassignment of instrumental functions within the gamelan orchestra. Traditionally, instrumental function has formed the basis for approaching music compositions. Hanging gongs were designated as punctuating colotomic markers, lower pitched single-octave metallophones provided nuclear melodies, and higher pitched multi-octave metallophones and kettle gongs were assigned elaborating melodies. Drummers played leadership roles within the orchestra. Today, however, instrumental functions are diverse and multiple, going beyond these traditional roles. In contemporary compositions all instruments have expanded functionality. These functionalities include supporting, leadership, elaborating, melodic, percussive roles. Assigning equally important status and a range of supporting and leadership functions to sections of the orchestra has led to new playing techniques such as double mallets, "dichord/trichord clusters, and alternative/juxtaposed voicing" (McGraw, 2009; Steele, 2013).

Craft of composition includes the deconstruction of traditional structural concepts. Traditionally, gamelan compositions have been based upon the analogy of the human body as a framework for tripartite musical form. Balinese gamelan music is analogous to the non-material components of the human body including bayu (physical and spiritual energy), sabda (emotive utterances of sound), and idep (aesthetic taste/cognitive logic). There is also a correlation between the upper, middle and lower parts of the physical body called tri angga. According to the Hindu concept, the triangga superstructure is related to the cosmological orientation of vertical and horizontal lines forming the macrocosms (bhuawana agung) and microcosms (bhuwana alit). The triangga reference serves as a basis for the Balinese gamelan form called jajar pageh which basically consists of three musical composition sections called kawitan (head) pangawak (main body), and pangecet (feet). Extending the analogy to the "head" as the controlling component, the first section of a musical composition is similar to the brain. Therefore, the function and character of the kawitan "head" in music is to establish recognition and identification similar to the brain's function in recognising people's faces and physical identities. Kawitan puts into operation, the functional organs or structural components of the body that constitute the second section of a composition called pangawak. In this way, the pangawak section in the analogy contains the vital organs of the human body (heart, liver, lungs, kidneys) which are mechanisms for the body to work as a whole. In this section music is arranged in accordance with orchestration methods such as patterning of melodic structures, and colotomic structures in a gong cycle which provide indicators of melodic form. The third and final section called pangecet is an inseparable part of the pangawak. It is a condensed form of the pangawak that determines the pathway towards the compositional climax (Asnawa, 2007, pp. 43-44).

Just a generation ago, composers relied on this concept to frame their creative works. Today, contemporary composers replace the concept of triangga with fragmented and juxtaposed ordering of musical sections using the term sungsang (overturned, reversed, flipped). This deconstruction of traditional compositional concepts may be observed in other musical elements. For example, incorporating binary and odd meters, symmetrical and a-symmetrical melodic groupings; stepwise melodies paired against melodies with large intervallic leaps; or harmonious voicing that suddenly 
transitions to disruptive cacophony. That said, changes to instrument function and using the sungsang approach may not always be easily understood by lay audiences. A composer who deconstructs traditional compositional architecture risks having the roof collapse around him if both "text and context" are totally abandoned. Innovations should still have a musical sensibility, not simply incorporate any random change or modification. Instead, it is necessary to understand the text and context of the art form by building aesthetic innovation through renewal of tradition with experimentalism and fusion forms.

\section{Innovation in Artist's Creative Work}

Giddens (2003) states that although there is a tendency to associate "globalisation" with Western domination in politics and power that weakens local cultures, it simultaneously makes local cultures painfully aware of the need to resurrect threatened cultural forms. It may be said that Bali is experiencing a "glocalisation process" where reassigning meaning to local cultural forms is necessary in the face of globalisation. Numerous cultural outputs including urban contemporary visual, plastic and sonic arts are responding to perceived threats from global cultural flows to ignite and encourage initiatives towards Ajeg Bali, a kind of Balinese revivalism (Hood, 2016). Ajeg Bali as a movement has been appropriated as part of a tourist centered promotional agenda picking up where "cultural tourism" or pariwisata budaya left off (Picard, 2008). However, there is also a grass roots movement (Bali kuat) that tends to strength social and cultural bonds and reaffirm Balinese identity in a sea of surging local identities in the nation (Kumbara, 2008).

From this glocalisation paradigm Balinese artists think critically about creative innovation. There are several examples of Balinese art forms that were revitalised from the brink of extinction through reconstruction efforts. It is on this basis that although the gamelan tradition has been regarded as having a stable and healthy development, there is still a need for using radical approaches. As Wayan Dibia states:

In general, artists in Bali do not allow their traditional arts to be frozen in time where every generation continually tries to innovate their art. Balinese artists are selective and incorporate new ideas into their inherited traditions because creativity is inherent in the art form. This turun-menurun process has the aim of breathing new life into the art and allowing the inheriting generation to create meanings within it. (Dibia, 1999, p.7)

For Balinese people, traditional and modern art exist side by side. Both art forms occupy a myriad of contexts. Both are given spaces and places according to their form and function. Although the people of Bali are very fanatical with their art traditions they can receive and appreciate works that breathe new life into stagnant forms.

\section{New Composers, New Gamelan}

In the following section, I present the innovations and achievements of six accomplished contemporary Balinese composers. I have made my selection based on what each composer brings to the discussion of innovation approaches to composition. In this way I hope to evidence the range of approaches from grassroots forms of reinventing tradition to radical departures from gamelan forms, tunings and instrumentation.

As Peter Steele writes of hybrids and fusions in Balinese music, “... Balinese fusion musics occupy multiple transcultural spaces ... as a formerly local art form transposed beyond place into a transnational multitude of artistic memes" (2013, p. 1). For this article on innovations in Balinese gamelan, I sat down with my composer colleague and friend, I Wayan Sudiarsa whose nickname is "Pacet". As a "community composer", Pacet is heavily involved with local artforms and he gestures out beyond to the transnational to enrich the local artistry around him. He attributes his innovations to two general categories: environmental themes and social impact. He also utilises a three-part strategy which includes his approach to developing tradition, hybridising tradition and composing in a non-traditional style. 


\section{Instrumental Music $\quad$ Dance Compositions $\quad$ Innovation Concepts $\quad$ Source of Inspiration}

\begin{tabular}{|c|c|c|c|}
\hline Sekar Gayot & Gairah Busa & & \\
\hline Manik Pering & Solah Jangkrik & & \\
\hline Ngapat & Cita Ulangun & Develop from Tradition & \\
\hline Banyuling & Murda Langon & & Social Impact \\
\hline Memargi 1 and 2 & Janger Ngapat & Hybridising Tradition & \\
\hline Gita Salsa & Songket Wali & & Environmental Themes \\
\hline Hredaya & Poleng Kesiman & Non-Traditional & \\
\hline Tetamanan & Pertiwi Jati & & \\
\hline Renggong Manis & Legu Gondong & & \\
\hline Sanghyang Sekar & Patemon Truna Daha & & \\
\hline Gelung Agung & Legong Jaya Baya & & \\
\hline Meong-meong & Murtining Panji & & \\
\hline Pulsinoge & & & \\
\hline
\end{tabular}

Figure 1. Social impact and environmental themes as sources of inspiration for innovative concepts guiding the repertoire of I Wayan Sudiarsa (Pacet).

Pacet is one of the principal leaders of Suling Gita Semara Gamelan Studio based in the village of Peliatan, just south of the tourist centre of Ubud. There are 35 active members of the Gamelan Gita Semara Studio. Pacet's initial capital investment of Rp 50,000,000 (approximately USD\$3,500.00) has allowed the group to maintain a schedule of monthly performances generating a modest income from wedding receptions, cultural events, religious ceremonies, festivals and tourist shows. The group charges a fee of between Rp 5 to 7 million (USD\$350-500) for music and dance performances.

Pacet has been actively composing musical works since 2004. He is well versed in composing for instrumental and dance compositions. The instrumental music he has composed for the gamelan gong suling includes such works as Sir Selisir, Sekar Gayot, Manik Pering, Ngapat where he combines the traditions of three types of vocal-based music including janger, the ritual chant called kecak and acapella folk music called genjek (Figure 1). He uses three principal innovation concepts: 1) develop from tradition; 2) hybridise tradition; and 3) non-traditional. The titles of his works include Tabuh Banyuling, Memargi 1, Memargi 2, Gita Salsa, Hredaya, Giri Putri, Tetamanan, Renggong Manis, and Sanghyang Sekar. An example of "non-traditional" innovations include Gelung Agung, Meong-meong and Pulsinoge, a suite of collaboration pieces between gamelan music and Western music. Pacet collaborated with Jakarta-based jazz producer and composer, Indra Lesmana and they have played together on several occasions including the Sanur Mostly Jazz Festival at the Griya Santrian Hostel on Sanur Beach in 2017. In Figure 1 in the second column are examples of Pacet's creative innovations for dance. These include such works as Murtining Panji dedicated to the 2nd Anniversary of ARMA Museum in 2017 and Gairah Busa in support of the final examination of Institut Seni Indonesia Denpasar students on behalf of Ary Sintya Dewi from Sibang - Badung.

Unlike his contemporaries who have achieved commercial recording contracts, collaborations with prestigious international universities, and generous government grants, Pacet thrives at the level of inter-group community networking. As a grassroots composer, his creative output may be viewed on social media and YouTube clips. The following is a partial listing of video recordings of innovative gamelan compositions by I Wayan Sudiarsa (Pacet):

1. Sekar Gayot https://www.youtube.com/watch?v=YLJliw7-Abc

\section{Tetamanan}

https://www.youtube.com/watch?v=qQa_qYjF368 
3. Janger Ngapat

https://www.youtube.com/watch?v=VqNvvt6NgPY\&list=RDIkVkoPJNIsA\&index=5

4. Oyod-Oyod

https://www.youtube.com/watch?v=dBGl2vPOkJo

5. Ngapat

https://www.youtube.com/watch?v=IkVkoPJNIsA

Inspiration for innovation in Pacet's compositions is attributed to two general categories: environmental themes and social impact (Figure 1). Besides actively working in his own studio, Pacet accepts commissions from other regencies in Bali such as Karangasem regency, particularly if the commission connects to the environment and has a social impact. As an example he composed Cricket Cage (Sangkang Jangkrik) dance music inspired by the dry season hobby of fighting crickets. This commission was for the Children's Kebyar Gong Ambassador competition from Karangsem in Rendang District in 2014 and helped with competitions, socialising, and education about the environment for children. Pacet feels that innovating with social impact in mind is critical for composers who care about passing down gamelan to subsequent generations.

As mentioned above, Pacet's approach to innovation utilises a three-part strategy which includes: 1) development of tradition; 2) hybridising tradition; and 3) non-tradition. He strives to make technical innovations by developing orchestration without drastically compromising aesthetic identity. He does this by relying on the method of reinterpretation rather than revolution. For example, rather than abandoning kotekan altogether, he chooses to reinterpret traditional interlocking melodic figuration patterns called ubit-ubitan and reapply them in new orchestrations with new instruments. That said, he is not a traditionalist who shies away from more radical ideas in gamelan. He does enjoy displacing patterns of predictable colotomic markers such gongs, and writing challenging drum patterns that depart from tradition.

Pacet's thematic approach to the creative process includes social impact and the natural environment. Most ideas or inspirations for Pacet arise from needs of the social circumstances that contextualise the performance of his pieces. He considers how the process of composition may have an impact on the people who inspire him to write in the first place. He asks himself, "who am I composing for?" His creative process begins with reflecting upon the needs of his audience so that his composition has social impact and engagement, rather than just being self-consumed with his own egotistical intellectualism. Supporting understanding his audience who supports him is critical to his innovation process. His ideas and concepts developed in tandem with the composition's social context will greatly affect the presentation of the work.

As a creative and productive artist, Pacet is very concerned about nurturing the younger generation with a spirit of devotion. In addition to actively fostering and creating works in several other arts organisations, to this day he also remains dedicated to fostering the younger generation in his village. Through his studio, he mentors four different groups fostering their growth and development without compensation. He donates his time because taking action, rather than just using words about making changes is important to him. Many composers isolate themselves away from the very communities from which they came. For Pacet, taking the time out of his schedule to foster elementary, junior high, and high school students, and a group of young women from junior and senior high school students in the village of Peliatan is like planting seeds in the soil from where he grew. He can harvest ideas for his own compositions, not just by mimicking international trends, but by simply giving back locally to his community and paying attention to the environment around him.

The next innovative composer is one of Bali's most accomplished kebyar innovators, I Nyoman Windha. Windha's approach to innovative music involves several elements including geographic setting, group musicianship, notation, melodic finalis and variations. The conceptual innovations of Balinese composer, I Nyoman Windha, clearly reflect the geographical setting of where he is composing. Often the location and setting inspires the title of his work and he may draw from local instruments such as rebana frame drums from Sumatra or erhu bowed lute from China. Innovation for him involves referencing geo-cultural aspects of where he is composing. Another approach to innovating involves evaluating the strengths and weaknesses of a group in terms of musicianship, and 
how best to compose for them. For example, Windha may compose special techniques for a gamelan group who have a talented quartet of reyong kettlegong musicians.

Notation also becomes a crucial step in stages of his compositions, particularly with regards to melody. By first notating a melodic idea and arranging it for various instruments such as reyong kettlegongs, kendang drums or gangsa metallophones, his initial concept can expand and develop to the instruments in the gamelan. This melodic concept will coalesce through his feeling and taste for where the large gong should fall. In other words, the musical taste and rhythmic emphasis is dramatically shaped according to when and where he feels the need to place the strike of the large gong. The gong as finalis is part of the heritage of gamelan and often determines the ending, and simultaneously the beginning of a cycle in gamelan music. Based on this melodic concept, he then chooses innovative techniques for interlocking melodic parts called kotekan. Melodic variations to complement his principal melody help accentuate polyrhythms so that heterophony occurs. Windha's use of notation in contemporary and heritage practices shows that, "aural tradition brings music notation to life and aural tradition dominates the heritage ensembles and musical landscape in Southeast Asia" (Hood, 2016, p. 54).

As an innovative composer, Windha has earned the reputation of being able to establish new concept and approaches in contemporary gamelan compositions without a total departure from gamelan tradition. Not only does he maintain traditional standards towards a sustainable form (Hood, 2017), he serves as a cutting-edge leader in the innovations of his tradition (Mack, 2001, p. 141). The strength of the melody in the works of I Nyoman Windha was also recognised by Dieter Mack when collaborating on the work of Catur Yuga from his interview. Windha admits that all of his compositions come from melody and never exclusively from abstract rhythms. The tune carries all because "within it can be felt all the other aspects of music such as rhythm and dynamics" (Mack, 2001, p. 139).

I turn now to a longtime friend and colleague of mine who lives in the same village as me, the village of Singapadu just south of Ubud. I spoke with composer I Wayan Darya from the Kebon community ward of Singapadu village about the innovations that led to the creating of a new gamelan. In the interview in January 2017, Darya mentioned that the new gamelan was created in 1996 and was called Gong Gede Saih Pitu. He stated that it was based on the classic court ensemble called gong gede that features single-octave resting keyed metallophones. However, he only got the idea after collaborating with a dancer named Guruh Soekarnoputra. "At that time I was working on a composition at Sanggar Putri Balerung Peliatan Ubud. The movements of the dancers and the storyline had the feeling of the classic gong gede, but I thought why not expand the instruments to the seven-tone scale" (Darya, personal communication, November 22, 2017).

Darya continued that a few months later there was a temple ceremony at his own village ward of Banjar Kebon, Singapadu. He discussed the idea to build an entirely new ensemble based on his experience with Soekarnoputra a few months earlier. Darya proposed the idea to make funds available in order to buy a Gamelan Gong Gede Saih Pitu. When the idea was spontaneously agreed the next day Darya ordered the new orchestra from the gamelan maker Mangku Pande Pager from Blahbatuh Village.

Darya says that all the repertoires produced on the Gong Gede Saih Pitu are all new, both in form and in musical language. This is to ensure that the new ensemble's form is capable of producing a repertoire that is unique in style and instrumentation (Darya, personal communication, February 13, 2017). The repertoire created to date includes: Hit Lulut, Asep Cina, Tabuh Dua Galang Bulan, Kembang Rampe, and Gegilakan performed by the group called Sekaa Gong Taruna Mekar from the Kebon community.

Another innovation in gamelan composition is the diatonically tuned seven-tone Semar Pagulingan of Bona Alit created in 1993. Because of the diatonic tuning, Bona Alit has collaborated with other ethnic and world music instruments including the concert harp, Sundanese drums, Chinese erhu, Indian sitar, bass guitar, drum set and electronic keyboards.

Since being established in 1993, Bona Alit art studio has produced a number of nuanced Balinese-Chinese/pan-Asian collaborations. These works include Zhen-zhen, Kang Ching Wie, Okinawa, Ngempu, Tegeh Ngolet, Wana Lara, Perahu Bencah, Kaja-kaja and Plasma O. His compositions produce musical shades and an atmosphere of peace, tranquility that are very pleasing to the ear. Even though Bona Alit incorporates these instruments into new arrangements, he still uses traditional Balinese gamelan motives as musical identity markers within his music. 


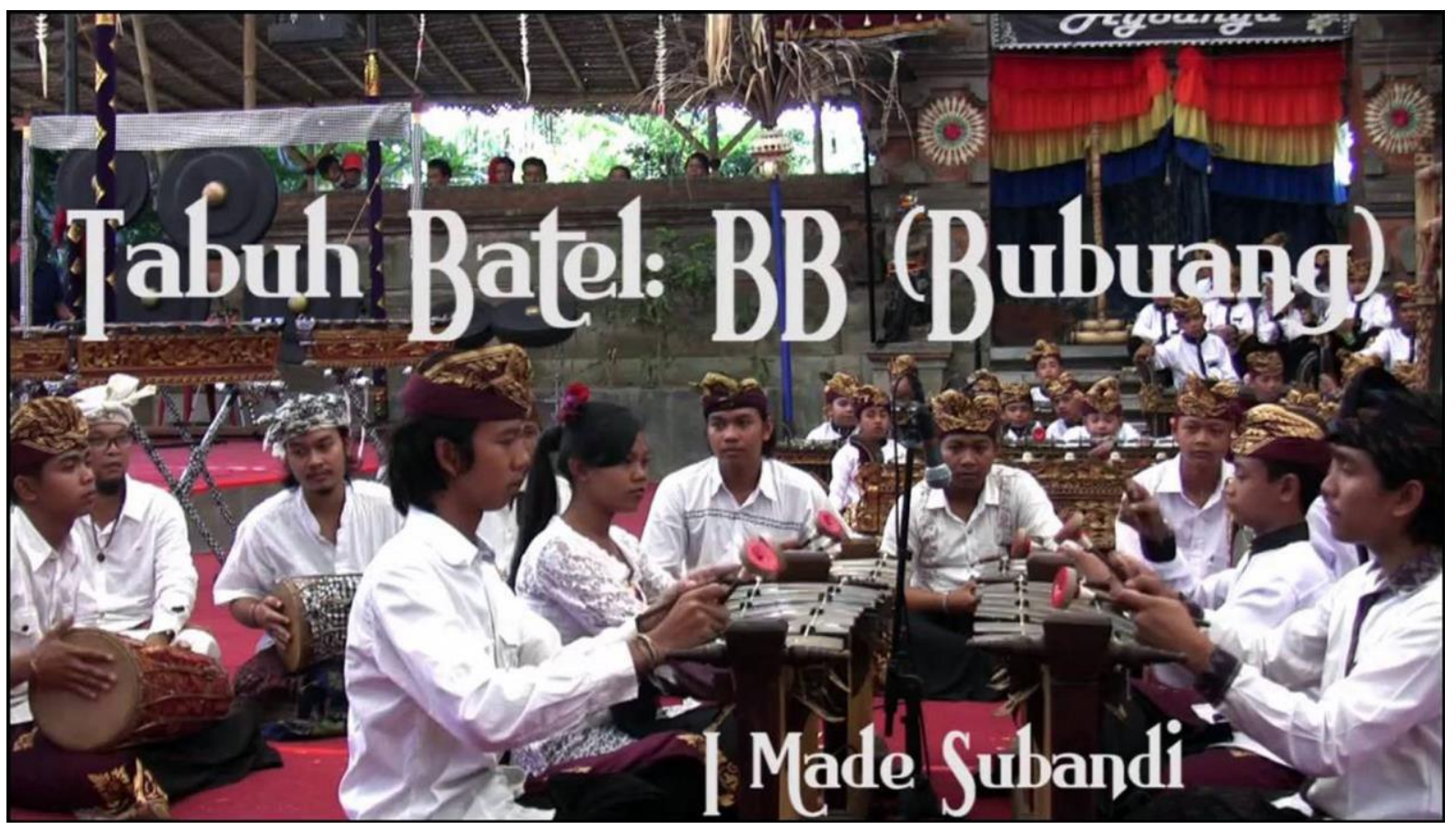

Figure 2. Composer I Made Subandi's composition 'Bubuang' as an example of his departures from existing styles to form 'radical traditional music'.

One gamelan innovator who adheres to new forms and functions is self-proclaimed radical composer I Made Subandi (Figure 2). In contrast to Bona Alit, Subandi's innovations are much more courageous by reinterpreting and giving new meaning to a deeply religious ensemble made of iron keys called selonding. He also frequently incorporates percussion instruments from Cambodia, Indian tabla, gong chimes from China among others. Through his group called Sanggar Ceraken he has produced a contemporary creative album called Semar Pagulingan Selonding. In fact, he labeled his work with the nickname "radical traditional music". Subandi's innovations are more courageous in deviating from existing patterns, styles and techniques. Other repertoire he has composed in this style includes KupuKupu Kuning, Blatuk Ngukul, AUM, Babuang, and Bibit (Subandi, personal communication, February 17, 2017).

The last composer I would like to discuss in this article is Dewa Ketut Alit from the village of Pengosekan-Ubud. He was born in 1973 in Pengosekan village in Bali. He has been surrounded by gamelan from childhood and his father, Dewa Nyoman Sura was very influential as his teacher during his early years. For his innovations, he engaged several gongsmiths to forge his own version of a seventone ensemble he named Salukat. Born into a family of musical artists, his intuition, personal sensitivity to sound and subsequent artistic innovations has earned him respect and admiration from his peers. With as much experience teaching, traveling and collaborating internationally as he has in Bali locally, he is regarded as a visionary for continually testing the boundaries of gamelan music. For the past 20 years Alit has been thinking about what new directions music will go and how these trends will manifest and be received. Armed with the sharpness of his intuition and his creative imagination combined with excellent technical ability, he has honed his skills in composition (Figure 3). 


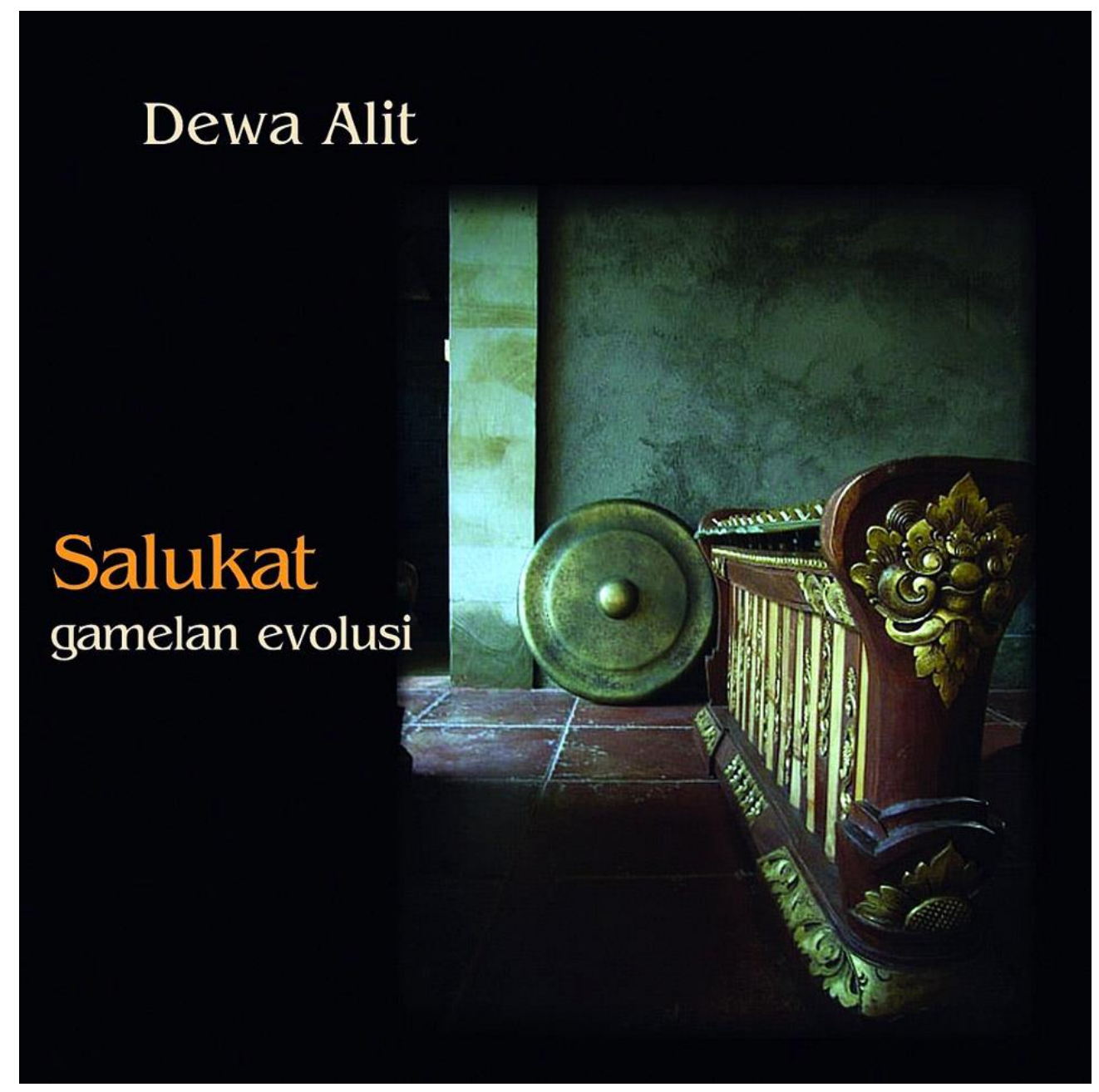

Figure 3. Composer Dewa Ketut Alit's referencing to the evolution of seven-tone music through his design and development of his own gamelan called Salukat.

Dewa Alit has developed his own "school of thought" in the field of gamelan. He did this by custom making and designing his own gamelan in 2007. The gamelan is called Salukat. The term salukat consists of the words salu and kat. Salu which means home, a common place, a place to depart from and return to in order to obtain peace of mind. Kat may be interpreted as a regeneration, a life cycle, that acknowledges the immutable position of living beings who are born, live, grow old and eventually die. But with this cycle is also rebirth into new forms.

In my interviews with Dewa Alit he proclaimed that gamelan Salukat was a medium to lift local cultural wisdom up to be reborn with each generation. However, Dewa Alit is well aware that the general expectations of the public are not entirely satisfied with his compositions. Dewa Alit says that, "I am not here to spoil the eyes and ears of just a local Balinese audience but rather I strive to produce innovative works with the values of local wisdom that meet the expectations of a global audience" (personal communication, February 12, 2017).

The titles of his compositions including Ngelanglang Ke Lelangu (2008), Murwa Daksina (2008), Salugambuh (2009) reflect Dewa Alit's love of nature and his homeland of Bali. In addition, his related works composed overseas such as Snow (snow), Aes (ice), and Universe (2009) show a strong connection for nature and the environment. The contestation of energy between opposing binaries is manifest in the sacred-profane, tradition versus modern themes represented in his work $d i$ Persimpangan Jalan (confused). Although known for his instrumental works, a selection of one of Dewa Alit's poems portrays the strength of local knowledge which comes from the teachings of religion about life cycles. The poem conveys a very deep, contemplative impression: 
Seconds, seconds, seconds, per second ... creeping in all directions of energy space, the vast expanse of Mother Earth, coupled with the of the sun, energy, thought and action bound with the good, bad, servants and kings, The earth rotates all the time, man is born alive and dead, take care of this planet!!! My earth, your earth, our earth is truth (poem by Dewa Alit)

Textually this poem may be interpreted to mean that no one has the power to stop the movement of time. Harmony in life involves the rotation of the earth and sun. Birth, life, and death will reincarnate all the time. Therefore, Dewa Alit reminds us to protect our planet that gives all of us blessings. In many ways, the innovative gamelan Salukat is a representation of the reincarnation of previous music that is now incarnated with a new face and character. It proceeds, it lives, it grows in time and space that is always moving rapidly and dynamically.

There has been a rise in Balinese artistic innovations in performing arts generally and composition specifically. Composers increasingly engage with critical discourses. These critical discourses include issues as social disharmony, damage to the environment, democratisation, and actualizing values of local wisdom as seen in Dewa Alit's music. These innovators seem to consciously resist homogenisation by raising issues of diversity and pluralism. Kumbara (2008, p. 201) states that globalisation not only pulls at that which causes homogenisation, but also pushes downward, exerting new pressures on local autonomy to give rise to new movements. Even when a local society fails in global competition it will return to its local tradition to serve as a means of struggle or uncompromising legitimacy through various pressures (Kumbara, 2004, p. 229). When globalisation tends to make culture homogeneous, it also encourages the desire of composers to come up with their own innovative ways to express themselves.

\section{Conclusion}

This article has examined innovative composers from Bali who are challenging tradition and producing new ensembles and art forms. Traditional frameworks combined with multi-cultural instruments and approaches from China, Korea, Western classical and popular music constitute cultural matrices that provide intersecting reference points for composers to source inspiration. Dramatically shaping and influencing not only melodies and rhythms, these changing local and cross-cultural matrices influence innovations in tuning and instrumentation as seen in the works of Darya and his Gong Gede Saih Pitu. The innovative approaches of Bona Alit and Subandi saw new compositions with Chinese and Japanese concepts further qualified by the individual creative process. These types of experiments have often been criticized by outsiders as inferior forms of composition rather than "authentic expressions in and of themselves" (McGraw, 2009, p. 129). However, composers like Dewa Alit who have traveled and studied abroad have returned to Bali to problematise the "inward versus outward" dichotomy in the development of Balinese performing arts.

The frequency of ritual activities in Bali and art performances at both cultural events and art festivals provides fertile opportunities for the creative ideas of artists to respond to the aesthetic needs of a rapidly modernising society. Conversely, this condition also provides opportunities for the enjoyment and appreciation of art. In the development of contemporary gamelan, Bali's displays of aesthetic change are based on a myriad of changing views on Hinduism where multi-cultural influences increasingly seep in through global flows (Bandem, 2013). These critical discourses include issues as social disharmony, damage to the environment, democratisation, and actualising values of local wisdom as seen in Dewa Alit's music. These innovators seem to consciously resist homogenisation by raising issues of diversity and pluralism.

Pacet's thematic approach to the creative process uses these global forms to make social impact and educate about the natural environment. His ideas arise from the needs and social circumstances of 
his community who contextualise music. Windha establishes new concepts and approaches in contemporary gamelan compositions without a total departure from gamelan tradition. Not only does his legacy stand for the maintenance of kebyar, he stood proudly as a cutting-edge leader breaking molds and revolutionising the genre. These advances in musical language speak to innovations in gamelan and serve as benchmarks that demarcate spaces within a composer's pallet of expression while simultaneously assessing the boundaries of changing traditions.

\section{References}

Asnawa, I. K. G. (2007). Khebinekaan dan kompleksitas Gamelan Bali. Bheri Jurnal Ilmiah Musik Nusantara, 6(1), 42-58.

Bandem, I. M. (2013). Balinese gamelan on the stage of history. STIKOM Bali Press.

Brinner, B. (1995). Cultural matrices and the shaping of innovation in central Javanese performing arts. Ethnomusicology, 39(3), 433-456.

Dibia, I. W. (1999). Art between tradition and modernization. Inaugural Professorial Address, Sekolah Tinggi Seni Indonesia Denpasar, May 1, 1999.

Giddens, A. (2003). Runaway world: How globalization is shaping our lives. Taylor \& Francis Press.

Harjana, S. (2003). Corat-coret: Music kontemporer dulu dan kini. Ford Foundation and Masyarakat Seni Pertunjukan Indonesia.

Hobsbawm, E. and Ranger, T. (1983). The invention of tradition. Cambridge University Press.

Hood, M. M. (2016). Notating heritage musics: Preservation and practice in Thailand, Indonesia and Malaysia. Malaysian Music Journal, 5(1), 53-73.

Hood, M. M. (2017). Recultivating local as a sustainable approach to the Bali arts festival. In P. Matusky and W. Quintero (Eds.), Proceedings of the $4^{\text {th }}$ Symposium: The ICTM Study Group on Performing Arts of Southeast Asia (pp. 73-76). School of Arts, Universiti Sains Malaysia.

Kumbara, A. (2004). Ethnicity and the rebirth of the political flow of the reform era of theoretical perspective. In I.W. Ardika and N.D. Putra (Eds.), Cultural politics and ethnic identity. (pp. 22-45). Fakultas Sastra, Universitas Udayana dan Balimangsi Press.

Kumbara, A. (2008). Ajeg Bali in the whirlwind flow of globalization of epistemological criticism. In Ardika, I. W. and Putra, N. D. (Eds.), The social dynamics of the Balinese society. (pp. 12-32).

Lindsay, J. (1991). Classical, kitch, contemporary: A study of Javanese performing arts. UGM Press.

Mack, D. (2001). Contemporary mosaics and intercultural issues. Artiline Press.

McGraw, A. (2009). Radical tradition: Balinese musik kontemporer. Ethnomusicology, 53(1), 115-141.

Picard, M. (2008). Balinese identity as tourist attraction: From 'cultural tourism' (pariwisata budaya) to 'Bali erect' (ajeg Bali). Tourist Studies, 8(2), 155-173.

Riandi, O. (2016). Pentingnya invensi dan inovasi bagi kemajuan bangsa. [Paper presentation]. Peningkatan Sumber Daya Ilmu Pengetahuan dan Pendidikan. Fakultas Sastra, Universitas Udayana dan Balimangsi Press.

Steele, P. M. (2013). Balinese hybridities: Balinese music as global phenomena (Unpublished doctoral dissertation). Wesleyan University Press.

Sugiartha, I. G. A. (2012). Balinese music creativity and new compositions: Perspectives on cultural studies. UPT Press.

Tenzer, M. (2000). Gamelan gong kebyar: The art of twentieth-century Balinese music. University of Chicago Press.

Tenzer, M. (2011). One fusion among many: Merging Bali, India and the West through modernism. Circuit: musiques contemporaines, 21(2), 77-100.

Wakeling, K. E. (2010). Representing Balinese music: A study of the practice and theorization of Balinese gamelan [Unpublished doctoral dissertation]. SOAS, University of London.

\section{Biography}

I Komang Sudirga is a lecturer at the Faculty of Performing Arts at the Indonesian Institute of Arts Denpasar in Bali, Indonesia. He is also the current dean of this faculty. I Komang has a master's degree from Universitas Gadjah Mada, Yogyakarta (1998-2001) and a doctoral degree in Cultural Studies from Universitas Udayana, Denpasar, Bali (2008-2012). After completing his studies, I Komang led several research projects as principal investigator and continued to perform as an active arts practitioner. I Komang has presented papers at international conferences and performed at several countries including Sweden (1991), Spain (1992), Germany, Switzerland, Belgium, the Netherlands, Finland (1995), Thailand (1996), Japan (1997, 2004), India (1998), Maldives (2007), Cambodia (2007), and France (2008). 